\title{
Studying Your Own Country. Social Scientific Knowledge For Our Times and Places
}

Presidential Address to the Canadian Political Science Association, St. Catharines, May 28,2014

AlAIN NoËL Université de Montréal

je n'ai jamais voyagé

vers autre pays que toi mon pays

Gaston Miron (1998 : 87)

\section{Introduction}

Political science is a global enterprise. Our theories, approaches and methodologies travel widely, and they evolve through international communications and deliberations. Our work is propelled by the natural desire to reach out and build explanations that account for important dimensions of the human experience, covering as much territory as possible, in time and in space. How many persons have the chance to share their workplace with specialists of democratisation in Africa, urban collective action in Latin America, identity politics in Eastern Europe, or the United Nations changing agenda?

Acknowledgements: I am grateful to Gabriel Arsenault, Michael Atkinson, Keith Banting, Linda Cardinal, Peter Graefe, Jane Jenson, Guy Laforest, Mireille Paquet, François Rocher, Denis Saint-Martin, and Graham White for comments and suggestions on earlier versions of this article.

Alain Noël, Département de science politique, Université de Montréal, C. P. 6128, succ. Centre-ville, Montréal, Québec, H3C 3J7. Email: alain.noel@umontreal.ca. 
At the same time, political science is also an anchored enterprise, focused on the here and now. Most of us study politics in the present tense and for a particular corner of the world, very often our own. When we do so, we do not abandon the aspiration to join in a broad, global conversation, but we give priority to more immediate preoccupations and interlocutors. My colleagues, for instance, also seek to understand the 'orange wave' in the last federal election, the ramifications of political corruption in Quebec politics, or the new modes of aboriginal governance in Canada. As they do, they insist less on general trends and mechanisms and more on the specificities of the cases at hand. They also interact more directly with their fellow citizens, and play a role, albeit modest, in their country's democratic conversations.

General and specific, global and national: these antinomies capture an enduring tension in the social sciences. Many scholars, for instance, challenge the "methodological nationalism" that governs our work, acknowledging at the same time that our reality - and the available data - remains very much defined by and around the nation-state (Dumitru, 2014: 9). This tension between global and national standpoints also has practical implications. Eager to publish in international venues, scholars often leave aside strictly national or local issues, seen as more difficult to sell to the dominant Anglo-American journals (Larivière, 2014). In principle, such a choice may seem a fair price to pay for increased visibility and impact. The impact of scholarly work, however, can be measured in more than one way. A study of social science journals use at the Universite de Montréal, for instance, finds that articles from Quebec journals are downloaded many times more than those published in leading international journals (Larivière, 2014). If impact is measured by readers' interest, national journals may be the best venue. Being anchored, connected to one's society, obviously matters.

Text Box about here (Le « choix » de la langue) 
I wish to use the occasion of this presidential address to reflect upon this tension between the appeals of a generalizing discipline and the requirements of an anchored, nationally relevant political science. My aim is not to advocate for one type of practice over the other. I think we should do both. The tension between the two orientations can in fact be creative. There is a need for a better balance, however, because the global perspective tends to crowd out and detract from national pursuits. This is so not only because international publications seem more prestigious than national ones, but also, and more importantly, because the general perspective often appears as more objective and scientific. Behind the international/national dichotomy, there are indeed rival conceptions of the social sciences, and important, but too often unexamined, ontological, epistemological and methodological assumptions.

This address starts from the discussion launched in 2008 by the publication of a book by colleagues from the University of Toronto entitled The Comparative Turn in Canadian Political Science (White et al., 2008), which advocated a more "exportoriented" discipline in Canada, and then considers three issues raised by the Comparative Turn project: the nature of social scientific knowledge and the critical and lasting contribution, in this respect, of idiographic, single-outcome studies; the importance, in social science, of producing relevant, usable knowledge; and the distinctive implications of studying one's own country, where a scholar is also a citizen, involved in more encompassing national conversations. Again, this is not an argument against an international social science or even against comparisons or the comparative method. It is more simply a plea in favour of maintaining as well, and in fact celebrating, the production of social scientific knowledge relevant for our own times and places, here and now.

\section{The Comparative Turn}

The Comparative Turn in Canadian Political Science celebrated a shift in research practices that was beginning to make the study of Canadian politics less 
"insular," "introspective," and "atheoretical," and more connected to the broader, global discipline. This shift, argued Linda White, Richard Simeon, Robert Vipond, and Jennifer Wallner was already advanced. "At some level," they contended, "we're all comparativists now" (2008: vii).

Engaged with the international community of scholars, Canadian political scientists would now be published broadly and, at least in some areas of knowledge, they would begin to be recognized not only as "takers" but also as "makers" of comparative theory (2008: viii). This call for a comparative turn had echoes as well among Quebec scholars, who published their own plea for a more explicitly comparative approach to the study of Quebec politics in a special issue of Politique et Sociétés (Fourot, Sarrasin and Holly, 2011).

At the outset, like many others, I welcomed the idea, being myself somewhere between comparative politics (and a bit of international relations) and Canadian and Quebec politics. These authors, I thought, basically celebrated what we already did. I became suspicious, however, when I saw a number of rather standard idiographic studies of Canada rebranded as comparisons, on the ground that at least they referred to concepts drawn from the comparative literature, something that presumably earlier work did not do. This is the argument made, for instance, by the contributors to a new volume entitled Comparing Canada: Methods and Perspectives on Canadian Politics (Turgeon, 2014: 12).

Was this "turn" for real? Did it proceed from a fair evaluation of our past? And was it well conceived from an ontological and epistemological standpoint? Or was it just another intellectual fad, a new way to describe and frame a well-worn area of expertise? Do not get me wrong. I am all for comparisons and I value the need to reach out to broader circles of scholarship, to join in the global conversations of our discipline. If I did not share these goals, I would not be addressing you in English today. But there was more to the proposed comparative turn than a simple outward-looking perspective. Necessarily, when we rethink our scholarly practices, we touch upon the ontological, 
epistemological and methodological foundations of our discipline. In other words, we make choices, consciously or not, that have scientific implications. What are indeed the ways of knowing associated with this presumably new approach to the study of Canadian and Quebec politics?

For one thing, the angle of the proposed comparative turn is not easy to measure. It is indeed far from obvious that our past, distant or more recent, can be characterized fairly as insular and introspective. When C. B. Macpherson wrote about democracy in Alberta in the early 1950s, it was to probe what he saw as a genuine "experiment in popular democracy" (1953). His book was designed, and received, as an assessment of innovative political practices with relevance for all electoral democracies. In FederalProvincial Diplomacy, published in 1972, Richard Simeon drew from international relations theory to study conflicts among governments in Canada (1972). Thirty-three years later, in 2005, the book obtained the Martha Derrick Best Book Award from the Federalism and Intergovernmental Relations Section of the American Political Science Association. In the 1970 s as well, Vincent Lemieux produced major studies of patronage, placing l'île d'Orléans and then all of Quebec in a broadly international comparative perspective (Lemieux, 1971 and 1977; Lemieux and Hudon, 1975). Closer to us, and to me, and more in the political economy tradition, Jane Jenson explained in the late 1980s how Canada's "permeable Fordism" was "different but not exceptional" (1989; 1990). These landmark contributions spanning many decades were all designed in a comparative perspective, and they certainly qualified their authors as "makers" of comparative scholarship. More recently, one could refer as well to the work of Sylvia Bashevkin (1998), Antonia Maioni (1998) or Gerard Boychuk (2009), which systematically compared Canada to other cases.

By contrast, the propositions included in The Comparative Turn often appear as uncertain comparisons. Canadians, notes Éric Montpetit, tend to explore the same themes as before, but are now more likely to publish their findings in international journals (2008: 32). The idea, proposes one contributor to the book is to see whether "Canadian answers to Canadian questions" are "applicable outside the Canadian 
context" (Robinson, 2008: 55). Others write similarly of a distinctively Canadian "narrative" that would offer a different standpoint to the world (Banting, 2008: 75; Tanguay, 2008: 193). Canada then becomes a "living laboratory" (Hirschl, 2008: 77), blessed by "fortunate circumstances" (Kymlicka, 2008: 120) or fashioned by unique difficulties (Hueglin, 2008: 140-41), which it faces with its own brand of "pragmatism" (Wallner, 2008: 174), to end up with a "particularly pronounced" specificity (Haddow, 2008: 231). This looks like a unique case indeed.

When it comes to Quebec politics, comparisons tend to be less optimistic, less likely to propose answers applicable elsewhere, but they also highlight the specific character of a society that may constitute a province, a stateless nation, or a regionstate (Cardinal and Papillon, 2011; Rigaud and Côté, 2011). "Étudier le Québec," writes Rachel Laforest, "c'est donc se pencher sur une histoire politique unique" (2011: 49).

Are we so far, then, along the comparative turn? Do we compare naturally and more fruitfully than did our predecessors? More importantly, should we define the study of Canadian and Quebec politics along the lines suggested in The Comparative Turn?

In the following pages, I want to address the latter question and reconsider what it means to study one's own country, from a social scientific point of view. Behind the notion of a comparative turn, there is indeed a certain idea of what is good political science, an idea that remains implicit, but has important implications.

This project assumes, indeed, that comparisons are, scientifically, more satisfying than case studies, which are themselves superior to single-outcome studies. The road to science would lead us unavoidably to comparisons, and the future of the study of Canadian and Quebec politics would very much look like comparative politics. I disagree. There is ample room for the study of politics in our own societies, informed but not guided by or limited to the logic of comparative politics. And this room is best understood as the pursuit of the venerable tradition of studying one's own country than as an application of the case-study procedure. 
When we study our own country, we do more than test a general theory. We seek to explain, and also understand, an aspect of our collective experience, and do so with the hope of producing usable knowledge and of engaging in the social and political life of our own society. These are noble objectives, about which we do not need to apologize. These three objectives - explaining, producing usable knowledge, and engaging - announce the themes I wish to address: the nature of scientific knowledge, the importance of usable knowledge, and the centrality of our own national conversations.

\section{Social Scientific Knowledge}

In a recent article published in Canadian Public Policy, Wayne Simpson and Herbert Emery document, and deplore, the decline of Canadian economics. Our fellow economists, they observe, publish less and less on Canadian questions, and this is particularly true of faculty hired since 1990 and of those working in the top-rated departments (2012: 466). They work "in Canada but not on Canada" (467). Presumably, they are less and less interested, as well, in teaching about Canada. Simpson and Emery conclude: "We use large amounts of tax dollars [no doubt an economist's worry...] to support research into and teaching about other economies so that our economists can be influential in other countries but not in Canada" (467).

There are some echoes of this preoccupation for the fate of Canadian issues in political science, but not as well documented, nor as serious (Tamburri, 2009). In any case, what is interesting here is less the warning than the responses, which are largely dismissive. Mike Veall, for instance, writes that this is an old lament, much less worrisome than it appears since "quantity is down, but average quality is up" (2013: 71). Andrew Leach observes that there is no lack of good reports on Canadian economic issues from a number of think thanks, and adds that, in any case, "economists know that people respond to incentives. Some of us will write about Canadian public policy 
because it's a passion, but others will not do so without reward" (2013: 73). And it is better that way, according to Kevin Milligan: "If my department were to trade off quality for more 'Canadian' researchers, my work would suffer" (2013: 71). Only Pierre Fortin concurs to deplore the gradual disappearance of the economist as public intellectual, fearing that the vacuum left by his colleagues may "leave the floor open for ideologues and charlatans to take over debates and increases the risk that bad policy decisions are" made (2013: 75).

Most economists, then, recognize the reality documented by Simpson and Emery, but do not share their conclusions. Why is this so? Why are economists so unconcerned by the decline of Canadian economics? On one level, they wish, like political scientists, to become "makers" of knowledge in their global discipline. Many say so, and this is fine. But there is more. Their benign reaction is also related to a view of social scientific knowledge that does not leave much room for the study of Canada qua Canada. Recall Milligan, who writes that we should not trade off quality for "Canadian" questions. Scholarship about Canada, in this perspective, risks compromising quality.

This evaluation stems less from prejudice than from ontology and epistemology. Milligan and most of his colleagues share a view of social science that, following Jonathon Moses and Torbjørn Knutsen, I will call naturalist, to use a term less laden with meaning and controversies than that of positivist (Moses and Knutsen, 2012: 8). How do naturalists see the world? They may differ on the specifics, but overall they agree that the universe around us is made of patterns and regularities, that exist independently of the observer and that can be assessed empirically. The very purpose of scientific research is to ascertain these regularities and develop general (nomothetic) and cumulative knowledge, relevant for all human beings (Moses and Knutsen, 2012: 8-9).

From a naturalist standpoint, the optimal approach is to conduct experiments, where causal relations can be inferred in a controlled setting, without context so to speak. When experiments are not possible, large $\mathrm{N}$ statistical analyses become the best alternative, to estimate the effects of a given cause in a controlled manner. And if the 
number of cases does not allow the use of quantitative techniques, the comparative method is the next best solution, allowing for some control for contextual effects. Sometimes, comparison itself is difficult or impossible. When this happens, a scholar can resort to case studies, where a single case is treated as "a case of something," an instance of a broader class of phenomenon (Lijphart, 1971; Moses and Knutsen, 2012: 49-50 and 133).

The case study, explains John Gerring, "attempts to tell us about something broader than the immediate subject of investigation" (2007: 83). The key question, then, is "what is this a case of?" (George and Bennett, 2005: 18). Is Quebec a small nation, a nation without state, or a state-region? Is Canada a multinational federation, a liberal welfare state, or an exemplary case of multiculturalism?

Note that not all single-country studies qualify as case studies. Often, scholars merely seek to explain "a single outcome for a single case" (Gerring, 2007: 187). We can then speak of a "single-outcome study." Why did Quebeckers vote so massively for the NDP in 2011? What accounts for the new politics of redistribution that started in the mid-1990s in Canada? How can we qualify the current party system in Canada? From a naturalist standpoint, such questions stand on the fringe of scientific activity, acceptable but marginal. For naturalist scholars, note John Gerring, if case studies "are bad enough," single-outcome analyses "are even worse" (2007: 190). To borrow from Milligan, we would definitively be at risk of trading off quality here.

But wait. Haven't we always done a lot of this and do we not rank such studies among the best? Isn't the single-outcome study often at the heart of what it means to study Canadian or Quebec politics? Consider, for instance, Misconceiving Canada by Kenneth McRoberts (1997). McRoberts has a causal theory, but it is rather singular theory (let's call it the "blame it on Trudeau" theory). His goal is less to validate a comparative theory than to demonstrate that a different end would have been possible (you may want to call it a counterfactual argument, but McRoberts does not quite say so). Note, as well, that the author never needs to go through a process deemed critical 
in the pursuit of case studies: the selection of cases. He does not have to answer the "what is this a case of" question. He just knows what he has to do.

A similar argument could be made for Donald Savoie's Governing from the Centre (1999), Peter Russell's Two Cheers for Minority Government (2008), Sylvia Bashevkin's Women, Power, and Politics: The Hidden Story of Canada's Unfinished Democracy (2009), or Alain-G. Gagnon's The Case for Multinational Federalism (2010). Savoie, Russell, Bashevkin and Gagnon are not "casing;" they primarily seek to understand what is going on in Canada. They propose causal explanations, and sometimes compare, but their main objective is less theory building than the probing of a given situation.

Consider, now, Matt James' Misrecognized Materialists (2006) or Stephanie Irlbacher-Fox's Finding Dashaa: Self-Government, Social Suffering and Aboriginal Policy in Canada (2009). James has a theory about social movements and representation, and so does Irlbacher-Fox, who points to the politics of social suffering and recognition. But these are constructivist theories, less about causality than about the way social actors constitute themselves. Are these books canonical comparisons or case studies? Neither really. Is this bad social science? I do not think so. I learned a lot from both books, and there is no doubt in my mind that they made good inferences informed by a strong theory.

My point, again, is that much of what we do stands outside the naturalist frame of reference. These unruly studies, however, do not compromise on "quality," and they should not be outlawed by epistemological or methodological fiat. They are worthy of our discipline and they are scientific because they practice inference, causal or descriptive, in a systematic and theoretically grounded way. And they deal with questions that matter. In this, Canadians are far from alone. Let me quote at some length from John Gerring's book on Case Study Research:

Every country, every region, every business, every era, every event, every individual - for that matter, every phenomenon that a substantial number of 
people care about - inspires its own single-outcome research agenda. Citizens of Denmark wonder why Denmark has turned out the way it has. ChineseAmerican immigrants wonder why this group exhibits certain sociological and political patterns. [...] Indeed, the vast majority of books and articles published in a given year are single-outcome analyses.

Social scientists, like lay citizens, are often interested in how their chosen subject of interest plays out in their country of origin. Thus, American economists study the American economy; American sociologists study American society; and American political scientists study American politics. [...] their concern in this genre of work is not a class of outcomes but rather a particular outcome or a set of outcomes pertaining to a particular country. It is not merely idle curiosity that fuels this sort of research. Understanding who we are - as individuals and as communities - rests, in part, on an understanding of what factors have made us who we are. (2007: 190-91)

To paraphrase the Comparative Turn, one could proclaim that "we're all insular and introspective now"!

I do not think the contributors to The Comparative Turn had these broader considerations in mind when they conceived their project. They certainly did not mention ontological and epistemological questions in their volume. As Stéphane Paquin notes, however, in his Politique et Sociétés essay on the matter, these questions are unavoidable (2011: 69-71). If we are to take a comparative turn and become "makers" of comparative theory, presumably it will be by considering Canada as a case, or as a series of instances of broader phenomena. From a naturalist standpoint, this move would bring us a step above in the hierarchy of methods, away from our introspective and insular traditions. The contributors to a new book entitled Comparing Canada, confront this question more openly and acknowledge the mild positivist stance that comes with "a fairly classic conception of scientific knowledge for which the objective is to explain causal relations and to isolate variables" (Papillon et al., 2014: 323).

Economists have largely converged on this positivist destination, because naturalism stands unchallenged in their discipline. But this need not be the case in political science.

For one thing, naturalism is challenged from within. An important movement in political science seeks to better acknowledge and integrate our own traditions of single- 
outcome, qualitative studies. Some, like Alexander George and Andrew Bennett, and probably John Gerring, do so by giving pride of place to the case study, this lowly approach at the bottom of the naturalist hierarchy of methods, and by proposing appropriate instruments for the work at hand, such as process-tracing. Others, like Gary Goertz and James Mahoney, go a step further by establishing the very distinctive nature of the qualitative enterprise, which looks at the causes of effects rather than at the effects of causes (2012). Again, the naturalist hierarchy of methods is seriously questioned, this time with even more appreciation for the pursuit of single-outcome studies.

Many go one step further and challenge naturalism itself. In the broad constellation of approaches that, again following Moses and Knutsen, we can call constructivist, the very foundations of naturalism are shaken. From a constructivist standpoint, the world is not a singular set of mechanisms that evolve independently from the observer, and it can never be accessed without interference. Facts themselves are social and value-laden, and reality can always be appraised in more than one way. More importantly, for our discussion, "knowledge gained by idiographic study is embraced in its own right" (Moses and Knutsen, 2012: 11). Because context matters so much for constructivists, single-outcome analyses move much higher in the hierarchy of methods, higher in fact than nomothetic studies, always suspected of lacking a good understanding of concrete situations (Moses and Knutsen, 2012: 202).

In Finding Dashaa, for instance, Stephanie Irlbacher-Fox goes to great length to make us see that the perspectives of Aboriginal peoples and government representatives are at a great distance from each other, and cannot be mediated in a simple, rational way (2009). This type of research is far from easy. In the last seven years, I have presided over a Quebec governmental research centre created to document poverty and social exclusion and assess the situation as it changes over time, the Centre d'étude sur la pauvreté et l'exclusion (www.cepe.gouv.qc.ca). Undoubtedly, the most difficult challenge we have faced has been to integrate into our work the standpoint of persons living in situations of poverty. The best I can say is that we have tried, and done so with good will and openness (see, for instance, Lechaume, 2014). 
For our discipline, and for the study of Canadian and Quebec politics in particular, I would make a plea for the same openness, for a perspective that is more conscious of its ontological foundations and deliberately plural in its views, where a softer form of naturalism could coexist with constructivist research. A few years ago, Peter Hall argued that comparativists, who are increasingly aware of the importance of context, of the complexity of causal processes, and of the centrality of ideas, discourses and agency, should better align their methodologies to their ontology, which no longer corresponds to a strict naturalist view of the world (2003). Similarly, I would argue, we should build the study of Canadian and Quebec politics in this more lucid and open perspective, and acknowledge that context-dependent single-outcome studies are not necessarily inferior.

We have done well, collectively, in understanding and interpreting our own societies. It would be a mistake to move the study of Canadian and Quebec politics away from these very strengths, just as comparative politics is opening up, to make more room for qualitative research designs, multiple causations, agency, and constructivist arguments. Our tradition is neither insular nor introspective. It has long been informed by international political science, but it has also relentlessly tried to explain who we are, for our own sake, as it should.

\section{Usable Knowledge}

As we recognize the scientific validity of single-outcome studies, and the possibility of a plurality of perspectives, we should also, in my opinion, take a moment to acknowledge that most, if not all, of what we do is driven by a sense of purpose. We are engaged in our own reality and seek to develop usable knowledge. And this knowledge, by necessity, is normative.

Let me use, here, a brief anecdote. A few years ago, at about this time of year, I was in Europe to participate in a dissertation jury. The thesis was about public support for foreign aid in OECD countries, a question on which I had done some work. The dissertation was good, but its purpose was not entirely clear to me and, to spice up the 
defense, I asked the author what he would say to Ida McDonnell - one of the core experts on public support for development assistance in the OECD headquarters in Paris - if he had a chance to meet her. The candidate was unable to answer the question. In fact, he did not really understand what I meant. He replied, more or less, that he had a solid theory and a reliable stock of available data, so that he could produce a fine dissertation. This was good science, period.

Well, to me, this was not good social science. Political science appeals to us precisely because it is about the real world. This does not mean that, as political scientists, we can produce authoritative work, and provide the last word on any given question. It implies simply that, as social scientists, we should try, and here I borrow the idea from Charles Lindblom, to develop "usable knowledge," knowledge that can enlighten and contribute to public debates, over real, important issues (Lindblom and Cohen, 1979). To do so, we are more or less compelled to take a stance. And we usually do. "Analysis without the underpinning of normative values and goals," noted Richard Simeon in the very last text he published, "is simply sterile" (2013: 282).

Those who read the work of Keith Banting, Gerry Boychuk, Peter Graefe, Jane Jenson or Rachel Laforest on Canadian social policies can easily understand that they care about the fate of our own version of the welfare state. Likewise, my Quebec colleagues who work on federalism - I am thinking in particular of Alain-G. Gagnon, Guy Laforest, and François Rocher - share a certain idea of what a well-functioning multinational federation should be about. The same can be said of American authors who have written in recent years on the tension between rising income inequalities and the working of American democracy. In Unequal Democracy, for instance, Larry Bartels writes: "The opinions of millions of ordinary citizens in the bottom third of the income distribution have no discernable impact on the behaviour of their elected representatives" (2008: 5). This is a factual statement, but it is also a normative call.

Last summer, Paul Pierson, a major contributor to theory building in comparative politics $(1994 ; 2004)$ was at the Université de Montréal to present his work. Speaking of his book with Jacob Hacker, Winner-Take-All Politics, I asked him what sort of 
comparative concept was the "politics of organized combat," a notion key to their argument (2010). He did not give a memorable answer, but what counted to me was his admission that, well, the United States is my country, the country I will leave to my children, and that really is what matters in this instance. He and Hacker were working hard to change the very terms of American politics. Here, we are moving into our third theme, national conversations, which stems naturally from the usable knowledge argument.

Before turning to this last theme, let us accept that scientific significance is best anchored in public relevance. And for this connection to be fruitful, choices have to be made and announced, just as they are, by the way, in medical research or climate science. To sum up so far, I would say one cheer for an open view of our discipline, one that would go beyond conventional naturalist accounts, and one cheer as well for an engaged discipline, which chooses not only cases, but also, in a way, causes.

\section{National Conversations}

Let me start, here, with another anecdote, which brings me back to my graduate student years in Denver, Colorado. I was studying in international studies, in a program that at the time counted a majority of foreign students. The African students, then, had their own scholarly gatherings, to which all were invited. One evening, my friend Ahmed Samatar, who was just back from fieldwork in his native Somalia, made a scathing presentation and told his fellow African students that doing interviews in Somalia where there was still a state at the time; these were the years of military dictator and self-proclaimed socialist Siad Barre - had been a true eye opener for him. We talk about neo-colonialism, imperialism, dependency theory, Ahmed said, but let's face it, Africa is doing badly to a large extent because its own elites are failing in their duties. We have to turn the critical and analytical lenses toward ourselves, he claimed in substance (see, for an early output of this research program, Samatar and Samatar, 1987). 
Let's just say, to make a long story short, that this message was not well received by the African students in attendance who, by and large, belonged to the continent's elites. In the debate that ensued, participants not from Africa largely remained on the sidelines. That day, the budding comparativist that I was understood that there are certain arguments that are best expressed and defended by a national, by someone who belongs to a given society. It struck me that, as a political scientist, there was a level of engagement that I could have in Canadian and Quebec politics, which would be more difficult to obtain for a society where I would remain, so to speak, a guest. Studying one's own society has its advantages, and this is not simply a matter of familiarity.

In his own, more sceptical, contribution to the Comparative Turn book, Alan Cairns reminds us that when we study our own country, we are a little more than scholars. We become, he proposes, citizen scholars (2008: 247). We practice political science, but we also contribute to our country's "stories of peoplehood," to borrow a term from Rogers M. Smith (2003). We partake in our national, or multinational, conversations. Feminists have long understood this intimate link between scholarship and politics. As Caroline Andrew explained in her own presidential address to this association, "our teaching and our writing does have an impact on the way in which Canadian society defines that which is political" (1984: 683).

In the constructivist tradition, this stance poses no problem. On the contrary, engagement is conducive to good research. In Making Social Science Matter, for instance, Bent Flyvbjerg explains that from his standpoint the very aim of social science is "to produce input to the ongoing social dialogue and praxis in a society, rather than to generate ultimate, unequivocally verified knowledge" (2001: 139). In this respect, being a citizen scholar is an advantage. American philosopher Richard Rorty speaks of "emotional involvement" to capture what is as stake:

National pride is to countries what self-respect is to individuals, a necessary condition for self-improvement. Too much national pride can produce bellicosity and imperialism, just as excessive self-respect can produce arrogance. But just as too little self-respect makes it difficult for a person to display moral courage, so insufficient national pride makes energetic and effective debate about 
national policy unlikely. Emotional involvement with one's country [...] is necessary if political deliberation is to be imaginative and productive. (1998: 3)

This reference to emotional involvement brings us back to our times. This winter, I was touched as I re-read with my students a recent essay by Guy Laforest, entitled "The Internal Exile of Quebecers in the Canada of the Charter" (2009). In this short piece, Guy captures very elegantly, and to me poignantly, our common political situation, which makes an object of pride in English Canada, the Charter of Rights and Freedoms, an ambivalent symbol in Quebec, one associated with a reluctance to recognize Quebec's national aspirations within the constitutional order. This difficulty does not prevent dayto-day accommodations, in politics as in civil society, as the harmonious working of our association demonstrates. But it leaves our country unachieved, to borrow a term from Rorty, or inauthentic, to follow Guy. And this impasse probably vitiates our academic conversations as well, as François Rocher demonstrates so convincingly in his 2007 article, "The End of 'Two Solitudes'? The Presence (or Absence) of the Work of FrenchSpeaking Scholars in Canadian Politics" (2007).

I have long hoped that, collectively, we could overcome this impasse and move to more authentic conversations. I am much less optimistic about this possibility now, just as I am more worried about achieving social justice in Quebec and in Canada. Perhaps the status quo is the best we can expect; or may be we should prepare for harsher, less hopeful or progressive political times.

My oldest daughter, Anne-Sophie, is just beginning studies in medicine. In one of her first classes, the professor told her group of new, incoming students something along these lines: you come to medicine thinking you will cure diseases and heal people; well, there is some of that, but mostly you will not cure diseases. Most of the time, you will help people live with their condition, manage the problem they have. This is a sobering thought, but as I grow older, I can see the wisdom of this warning, and its relevance for political science. 


\section{Conclusion}

Through a somewhat meandering walk, I took you from the Comparative Turn to our enduring constitutional impasse, and from my formative experiences as a graduate student to my current life as the father of a teenager and a young adult. Let me summarize briefly my conclusions and leave you with one or two final thoughts. I have argued, first, that as political scientists we can pursue idiographic, single-outcome studies, without having to disguise them as case studies or as comparative contributions. Only in the stricter naturalist reading is this type of work inferior, of lesser quality than nomothetic studies. It can even be claimed that, when context appears important, idiographic studies provide the best road to knowledge. Second, I have proposed that we should not hesitate, indeed we should embrace, a normative commitment to produce usable knowledge. Good social science requires clear, explicit engagement with our societies' challenges. Finally, I have suggested that we should accept openly, and in fact take pride in our status as citizen scholars, of our country but also of the world. When I wrote about the Left and the Right in Global Politics, with my colleague Jean-Philippe Thérien, we were always clear that we wrote about "our world" (2008).

In a book entitled What Democracy is For, which is largely a book about his own country, Norwegian sociologist Stein Ringen argues that modern democracies fall short in many ways: money often trumps votes, participation and citizen engagement are low and declining, confidence in politics is eroding, and the welfare state fails to protect all citizens against the risk of poverty (2007: 219-21). Even Norway, writes Ringen, a rich and peaceful country with a strong democratic record and generous social programs, often appears inadequate, with declining participation, ill-working representation mechanisms, and an emerging immigrant underclass (256-68). Poverty, in particular, remains a preoccupation, even with a model social-democratic welfare state. Ringen proposes a number of democratic and social reforms, but he mostly reminds us that our work, as citizen scholars, is never finished. And this work is not less worldly because it concerns our lives and that of our fellow citizens. 
I opened this address with a 1963 line from Quebec's master poet Gaston Miron. Let me close with a 1803 passage from another well-known poet, William Blake (2008: 490):

To see a World in a Grain of Sand And a Heaven in a Wild Flower Hold Infinity in the palm of your hand, And Eternity in an hour 


\section{References}

Andrew, Caroline. 1984. "Women and the Welfare State." Canadian Journal of Political Science. 17 (4): 667-83.

Banting, Keith G. 2008. "Canada as Counternarrative: Multiculturalism, Recognition, and Redistribution." In The Comparative Turn in Canadian Political Science, ed. Linda White, Richard Simeon, Robert Vipond, and Jennifer Wallner. Vancouver: UBC Press.

Bartels, Larry M. 2008. Unequal Democracy: The Political Economy of the New Gilded Age. Princeton: Princeton University Press.

Bashevkin, Sylvia. 1998. Women on the Defensive: Living Through Conservative Times. Chicago: University of Chicago Press.

Bashevkin, Sylvia. 2009. Women, Power, and Politics: The Hidden Story of Canada's Unfinished Democracy. Oxford, Oxford University Press.

Blake, William. 2008. The Complete Poetry and Prose of William Blake. Berkeley: University of California Press.

Boychuk, Gerard W. 2008. National Health Insurance in the United States and Canada: Race, Territory and the Roots of Difference. Washington: Georgetown University Press.

Cairns, Alan C. 2008. "Conclusion: Are We on the Right Track?" In The Comparative Turn in Canadian Political Science, ed. Linda White, Richard Simeon, Robert Vipond, and Jennifer Wallner. Vancouver: UBC Press.

Cardinal, Linda et Martin Papillon. 2011. "Le Québec et l'analyse comparée des petites nations." Politique et Sociétés. 30 (1): 75-93.

Dumitru, Speranta. 2014. "Qu'est-ce que le nationalisme méthodologique? Essai de typologie." Raisons politiques. 54: 9-22.

Flyvbjerg, Bent. 2001. Making Social Science Matter: Why Social Inquiry Fails and How it Can Succeed Again. Cambridge: Cambridge University Press.

Fortin, Pierre. 2013. “Join the Fray." Policy Options. November-December: 74-75.

Fourot, Aude-Claire, Rachel Sarrasin, and Grant Holly. 2011. "Comparer le Québec: approches, enjeux, spécificités." Politique et sociétés. 30 (1): 3-18. 
Gagnon, Alain-G. 2010. The Case for Multinational Federalism: Beyond the AllEncompassing Nation. London: Routledge.

George, Alexander L. and Andrew Bennett. 2005. Case Studies and Theory Development in the Social Sciences. Cambridge: MIT Press.

Gerring, John. 2007. Case Study Research: Principles and Practices. Cambridge: Cambridge University Press.

Goertz, Gary and James Mahoney. 2012. A Tale of Two Cultures: Qualitative and Quantitative Research in the Social Sciences. Princeton: Princeton University Press. Hacker, Jacob S. and Paul Pierson. 2010. Winner-Take-All Politics: How Washington Made the Rich Richer, and Turned Its Back on the Middle Class. New York: Simon and Schuster.

Haddow, Rodney. 2008. "How Can Comparative Political Economy Explain Variable Change? Lessons for, and from, Canada." In The Comparative Turn in Canadian Political Science, ed. Linda White, Richard Simeon, Robert Vipond, and Jennifer Wallner. Vancouver: UBC Press.

Hall, Peter A. 2003. "Aligning Ontology and Methodology in Comparative Research." In Comparative Historical Analysis in the Social Sciences, ed. James Mahoney and Dietrich Rueschemeyer. Cambridge: Cambridge University Press.

Hirschl, Ran. 2008. "Canada's Contribution to the Comparative Study of Rights and Judicial Review." In The Comparative Turn in Canadian Political Science, ed. Linda White, Richard Simeon, Robert Vipond, and Jennifer Wallner. Vancouver: UBC Press.

Hueglin, Thomas O. 2008. "Working around the American Model: Canadian Federalism and the European Union." In The Comparative Turn in Canadian Political Science, ed. Linda White, Richard Simeon, Robert Vipond, and Jennifer Wallner. Vancouver: UBC Press.

Irlbacher-Fox, Stephanie. 2009. Finding Dashaa: Self-Government, Social Suffering and Aboriginal Policy in Canada. Vancouver: UBC Press.

James, Matt. 2006. Misrecognized Materialists: Social Movements in Canadian Constitutional Politics. Vancouver: UBC Press. 
Jenson, Jane. 1989. "'Different' but not 'Exceptional': Canada's Permeable Fordism." Canadian Review of Sociology. 26 (1): 69-94.

Jenson, Jane. 1990. "Representations in Crisis: The Roots of Canada's Permeable Fordism." Canadian Journal of Political Science. 23 (4): 653-84.

Kymlicka, Will. 2008. "Marketing Canadian Pluralism in the International Arena." In The

Comparative Turn in Canadian Political Science, ed. Linda White, Richard Simeon, Robert Vipond, and Jennifer Wallner. Vancouver: UBC Press.

Laforest, Guy. 2009. "The Internal Exile of Quebecers in the Canada of the Charter." In Contested Constitutionalism: Reflections on the Canadian Charter of Rights and Freedoms, ed. James B. Kelly and Christopher Manfredi. Vancouver: UBC Press.

Laforest, Rachel. 2011. "L'étude du tiers secteur au Québec: comment saisir la spécificité québécoise?" Politique et Sociétés. 30 (1): 43-55.

Laponce, Jean. 2006. Loi de Babel et autres régularités des rapports entre langue et politique. Québec : Presses de l'Université Laval.

Larivière, Vincent. 2014. "De l'importance des revues de recherche nationales." Découvrir, septembre (http://www.acfas.ca/publications/decouvrir/09/2014 ).

Leach, Andrew. 2013. "No Crisis." Policy Options. November-December: 72-73.

Lechaume, Aline, with the collaboration of Dominique Brière. 2014. L'exclusion sociale: construire avec celles et ceux qui la vivent; vers des pistes d'indicateurs d'exclusion sociale à partir de l'expérience de personnes en situation de pauvreté. Québec: Centre d'étude sur la pauvreté et l'exclusion.

Lemieux, Vincent. 1971. Parenté et politique: l'organisation sociale dans l'île d'Orléans.

Québec, Presses de l'Université Laval.

Lemieux, Vincent. 1977. Le patronage politique: une étude comparative. Québec, Presses de l'Université Laval.

Lemieux, Vincent et Raymond Hudon. 1975. Patronage et politique au Québec: 19441972. Québec, Boréal Express.

Lijphart, Arend. 1971. "Comparative Politics and the Comparative Method," American Political Science Review. 65 (3): 682-93.

Lindblom, Charles and David K. Cohen. 1979. Usable Knowledge : Social Science and Social Problem Solving. New Haven : Yale University Press. 
Macpherson, C. B. 1953. Democracy in Alberta: The Theory and Practice of a QuasiParty System. Toronto: University of Toronto Press.

Maioni, Antonia. 1998. Parting at the Crossroads: The Emergence of Health Insurance in Canada and the United States. Princeton: Princeton University Press.

May, Stephen. 2003. "Misconceiving Minority Language Rights: Implications for Liberal Political Theory." In Language Rights and Political Theory, ed. Will Kymlicka and Alan Patten. Oxford: Oxford University Press.

McRoberts, Kenneth. 1997. Misconceiving Canada: The Struggle for National Unity.

Toronto: Oxford University Press.

Milligan, Kevin. 2013. "Get Better Data." Policy Options. November-December: 71-72.

Miron, Gaston. 1998. L'homme rapaillé. Montréal: Typo.

Montpetit, Éric. 2008. "A Quantitative Analysis of the Comparative Turn in Canadian

Political Science." In The Comparative Turn in Canadian Political Science, ed. Linda

White, Richard Simeon, Robert Vipond, and Jennifer Wallner. Vancouver: UBC Press.

Moses, Jonathon W. and Torbjørn L. Knutsen. 2012. Ways of Knowing: Competing Methodologies in Social and Political Research. Second Edition. Houndmills, Basingstoke: Palgrave Macmillan.

Noël, Alain and Jean-Philippe Thérien. 2008. Left and Right in Global Politics. Cambridge: Cambridge University Press.

Papillon, Martin, Luc Turgeon, Jennifer Wallner and Stephen White. 2014. "Conclusion."

In Comparing Canada: Methods and Perspectives on Canadian Politics, ed. Luc Turgeon, Martin Papillon, Jennifer Wallner, and Stephen White, Vancouver: UBC Press.

Paquin, Stéphane. 2011. "Bouchard, Durkheim et la méthode comparative positive." Politique et Sociétés. 30 (1): 57-74.

Patten, Alan and Will Kymlicka. 2003. "Introduction: Language Rights and Political Theory: Context, Issues, and Approaches." In Language Rights and Political Theory, ed. Will Kymlicka and Alan Patten. Oxford: Oxford University Press.

Pelletier, Alexandre and Richard Simeon. 2012. "Groupes linguistiques et société civile: confiance, coopération et accommodements au sein des associations volontaires au 
Canada." In La dynamique confiance/méfiance dans les démocraties multinationales: le Canada sous l'angle comparatif, ed. Dimitrios Karmis and François Rocher. Québec : Presses de l'Université Laval.

Pierson, Paul. 1994. Dismantling the Welfare State? Reagan, Thatcher and the Politics of Retrenchment. Cambridge, Cambridge University Press.

Pierson, Paul. 2004. Politics in Time: History, Institutions, and Social Analysis. Princeton, Princeton University Press.

Rigaud, Benoît et Louis Côté. 2011. "Comparer l'État québécois: pertinence et faisabilité." Politique et Sociétés. 30 (1): 19-41.

Ringen, Stein. 2007. What Democracy Is For: On Freedom and Moral Government. Princeton: Princeton University Press.

Robinson, Andrew M. 2008. "Is Canadian Multiculturalism Parochial? Canadian Contributions to Theorizing Justice and Ethnocultural Diversity." In The Comparative Turn in Canadian Political Science, ed. Linda White, Richard Simeon, Robert Vipond, and Jennifer Wallner. Vancouver: UBC Press.

Rocher, François. 2007. "The End of 'Two Solitudes'? The Presence (or Absence) of the Work of French-Speaking Scholars in Canadian Politics." Canadian Journal of Political Science. 40 (4): 833-57.

Rorty, Richard. 1998. Achieving Our Country: Leftist Thought in Twentieth-Century America. Cambridge: Harvard University Press.

Russell, Peter H. 2008. Two Cheers for Minority Government: The Evolution of Canadian Parliamentary Democracy. Toronto: Emond Montgomery.

Samatar, Abdi, and Ahmed I. Samatar. 1987. "The Material Roots of the Suspended African State: Arguments from Somalia." Journal of Modern African Studies. 25 (4): 669-90.

Savoie, Donald J. 1999. Governing from the Centre: The Concentration of Power in Canadian Politics. Toronto: University of Toronto Press.

Simeon, Richard. 1972. Federal-Provincial Diplomacy: The Making of Recent Policy in Canada. Toronto: University of Toronto Press. 
Simeon, Richard. 2013. "Reflections on a Federalist Life." In The Global Promise of Federalism, ed. Grace Skogstad, David Cameron, Martin Papillon, and Keith Banting. Toronto: University of Toronto Press.

Simeon, Richard and David Cameron. 2009. "Accommodation at the Pinnacle: The Special Role of Civil Society's Leaders." In Language Matters: How Canadian Voluntary Associations Manage French and English, ed. David Cameron and Richard Simeon. Vancouver: UBC Press.

Simpson, Wayne and J. C. Herbert Emery. 2012. "Canadian Economics in Decline: Implications for Canada's Economics Journals." Canadian Public Policy. 38 (4): 44570.

Smith, Rogers M. 2003. Stories of Peoplehood: The Politics and Morals of Political Membership. Cambridge: Cambridge University Press.

Sonntag, Selma K. and Linda Cardinal. 2015. "State Traditions and Language Regimes: Conceptualizing Language Policy Choices." In State Traditions and Language Regimes, ed. Linda Cardinal and Selma K. Sonntag. Montréal and Kingston: McGillQueen's University Press.

Tamburri, Rosanna. 2009. "The Fall of Canadian Politics: No One's Studying Canadian Politics Anymore, or Not the Way They Used To. Should We Care?" University Affairs, January 12.

Tanguay, A. Brian. 2008. "What's So Bad about Cultivating Our Own Theoretical Gardens? The Study of Political Parties in Canada." In The Comparative Turn in Canadian Political Science, ed. Linda White, Richard Simeon, Robert Vipond, and Jennifer Wallner. Vancouver: UBC Press.

Turgeon, Luc. 2014. "Introduction." In Comparing Canada: Methods and Perspectives on Canadian Politics, ed. Luc Turgeon, Martin Papillon, Jennifer Wallner, and Stephen White, Vancouver: UBC Press.

Veall, Mike. 2013. "Quality, Not Quantity." Policy Options. November-December: 71.

Wallner, Jennifer. 2008. "Empirical Evidence and Pragmatic Explanations: Canada's Contributions to Comparative Federalism." In The Comparative Turn in Canadian Political Science, ed. Linda White, Richard Simeon, Robert Vipond, and Jennifer Wallner. Vancouver: UBC Press. 
White, Linda, Richard Simeon, Robert Vipond, and Jennifer Wallner. 2008. "Preface and Acknowledgements." In The Comparative Turn in Canadian Political Science, ed. Linda White, Richard Simeon, Robert Vipond, and Jennifer Wallner. Vancouver: UBC Press. 


\section{Text Box}

\section{Le « choix » de la langue}

Dans un moment pareil, pour un Québécois, la question de la langue se pose nécessairement. Le discours présidentiel n'est-il pas une bonne occasion de donner à notre langue un peu plus de place dans les délibérations de l'Association canadienne de science politique? Et comment parler avec une certaine profondeur de son pays sans utiliser sa propre langue? J'ai beaucoup réfléchi à cette question, et j'aurais aimé faire cette présentation en français. Mais je ne l'ai pas fait.

J'apprécie le fait que l'Association canadienne de science politique puisse offrir à ses membres un minimum de services en français. En cela, notre association se conforme au principe de personnalité, qui reconnait des droits linguistiques individuels et fonde le bilinguisme canadien (Patten et Kymlicka, 2003 : 29). Force est de constater, cependant, que la vie de l'association - son Assemblée générale, les réunions de l'exécutif et du conseil, le congrès annuel - se déroule pour l'essentiel en anglais. Dans l'histoire de l'association, seuls deux présidents ont fait leur discours en français: le père Georges-Henri Lévesque, le premier président francophone, en 1952, et Léon Dion, en 1975. En cela également, notre association est très canadienne. Dans la vie publique du pays, en effet, l'anglais domine, comme il prévaut dans les contacts personnels entre francophones et anglophones (Laponce, 2006 : 146).

Dans leur étude sur les langues officielles dans les associations canadiennes, Richard Simeon et David Cameron parlent de «bilinguisme asymétrique » pour rendre compte d'une telle situation (2009: 179). Ce sont les francophones, observent-ils, qui doivent s'ajuster à un environnement anglophone, et non l'inverse. Les auteurs suggèrent qu'il y a là plus un effet du nombre qu'une forme active de discrimination ou d'exclusion. Mais ils ne peuvent nier les effets politiques d'une telle situation. L'exercice du pouvoir dans les associations, reconnait Simeon dans une analyse cosignée avec Alexandre Pelletier, se réalise " encore principalement en anglais » (2012 : 250). Et il 
est difficile de penser que cette asymétrie n'a pas d'effets sur les choix considérés, et en fait sur la communication elle-même, comme le montre l'étude de François Rocher sur la faible circulation des idées des politologues francophones auprès de leurs collègues anglophones (Rocher, 2007; Sonntag et Cardinal, 2015).

Mais cette asymétrie linguistique est inhérente à la situation canadienne, et elle est renforcée par le statut de l'anglais comme lingua franca planétaire, "la plus puissante des langues universelles que le monde ait connues" (Laponce, $2006: 13$ ). L'usage de l'anglais pour la communication scientifique devient donc, pour reprendre les termes de Stephen May, quelque chose comme un « choix forcé » (2003: 150).

Pour le minoritaire, explique avec sagesse Jean Laponce, la seule solution consiste à jouer sur les deux tableaux, c'est-à-dire à utiliser la langue majoritaire pour s'inscrire dans les délibérations de la société plus large, et en l'occurrence du monde, tout en protégeant et promouvant sa langue dans des institutions séparées, idéalement associées à un territoire distinct (2006: 146). "La stratégie gagnante », écrit Laponce de façon imagée, « consiste à voyager et à rester chez soi » (16).

C'est donc en anglais, la langue réelle de l'Association canadienne de science politique, et la langue du voyage, que j'ai «choisi » de présenter cette allocution présidentielle. 